Publisher's Note

Opt. Eng. 44, 103601 (October 2005)

\title{
Analysis of characteristic param- eters of a plasma ion source and of ion-assisted deposited optical thin films
}

\author{
Ö. Faruk Farsakoğlu \\ Turkish Land Forces Logistics Command \\ Optics Projects Management Division \\ 06110 Gümüşdere \\ Ankara, Turkey
}

The above-listed paper has been removed from the SPIE Digital Library due to the discovery that significant portions of the text, figures, and equations were taken directly, and without proper credit and additional research originality, from the following previously published papers by other researchers:

D. E. Morton and V. Fridman, "Measurement and Correlation of Ion Beam Current Density to Moisture Stability of Oxide Film Stacks Fabricated by Cold Cathode Ion Assisted Deposition," 41st Annual Technical Conference Proceedings, Society of Vacuum Coaters, pp. 297302 (1998).

O. Zabeida, J. E. Klemberg-Sapieha, L. Martinu, and D. E. Morton, "Ion Bombardment Characteristics During the Growth of Optical Films Using a Cold Cathode Ion Source," 42nd Annual Technical Conference Proceedings, Society of Vacuum Coaters, pp. 267-272 (1999).

D. E. Morton, "The Effects of Pumping Speed on the Operation of a Cold Cathode Ion Source," 43rd Annual Technical Conference Proceedings, Society of Vacuum Coaters, pp. 207-211 (2000).

As stated in the SPIE Publication Ethics Guidelines, "SPIE defines plagiarism as the reuse of someone else's prior ideas, processes, results, or words without explicit attribution of the original author and source.... SPIE considers plagiarism in any form to be unacceptable and a serious breach of professional conduct." Therefore, this paper was removed from the SPIE Digital Library on November 16, 2007. The citations are provided here so that interested readers can access the information from the original sources. 